\author{
RENATA BABIŃSKA-GÓRECKA \\ ORCID: 0000-0002-9893-3276 \\ Uniwersytet Wrocławski \\ Zakład Prawa Pracy \\ Instytut Prawa Cywilnego
}

\title{
ZAGADNIENIE STOSOWANIA PRZEPISÓW KODEKSU CYWILNEGO DO OKREŚLENIA NIEKTÓRYCH NASTĘPSTW RELACJI PŁATNIK-UBEZPIECZONY Z PUNKTU WIDZENIA ZAŁOŻENIA RACJONALNOŚCI PRAWODAWCY
}

\begin{abstract}
Abstrakt: Artykuł poddaje analizie problem dopuszczalności oraz podstaw prawnych dochodzenia przez płatnika składek od ubezpieczonego zwrotu części zapłaconej składki ze środków własnych płatnika, którą w myśl ustawy finansuje ubezpieczony. W opracowaniu podjęto próbę oceny, czy mamy tu do czynienia $\mathrm{z}$ luką w prawie ubezpieczeń społecznych, ewentualnie czy można na innej podstawie - stosując przepisy kodeksu cywilnego o bezpodstawnym wzbogaceniu czy spełnieniu świadczenia przez osobę trzecią — formułować odpowiednie roszczenie regresowe płatnika składek względem ubezpieczonego. Punktem odniesienia prowadzonych rozważań oraz interpretacji przepisów prawnych uczyniono założenia o racjonalności językowej i aksjologicznej prawodawcy.

Słowa kluczowe: płatnik składek, ubezpieczony, prawo cywilne, prawo ubezpieczeń społecznych, założenie racjonalności prawodawcy
\end{abstract}

\section{WPROWADZENIE}

W doktrynie prawa ubezpieczeń społecznych, rok po wejściu w życie reformy ubezpieczeń społecznych, wyrażono pogląd, że „określoną część składki, która nie została przekazana przez pracodawcę, można ściągać bezpośrednio od pracownika”, zastrzegając jednak, że „nie wydaje się zasadne, by był on [pracownik R.B.-G.] pociągany do odpowiedzialności z tytułu zalegania z opłaceniem składki, jeżeli zaniedbania w tym zakresie obciążają wyłącznie pracodawcę" .

$\mathrm{Z}$ kolei praktykę dochodzenia przez pracodawcę zwrotu zapłaconej w takich okolicznościach składki od pracowników na podstawie przepisów kodeksu cywil-

1 W. Sanetra, Pracownik i płatnik składki, PUSiG 2000, nr 1, s. 2. 
nego o bezpodstawnym wzbogaceniu zaakceptował SN w uchwale z dnia 5 grudnia $2013 \mathrm{roku}^{2}$.

Koncepcja ukształtowania relacji płatnik-ubezpieczony przez subsydiarne lub per analogiam zastosowanie przepisów kodeksu cywilnego, jeżeli doszło do opłacenia przez płatnika z własnych środków części składki, finansowanej przez ubezpieczonego, to jest bez potrącenia jej z przychodu ubezpieczonego, budzi istotne wątpliwości.

Warto dodać, że sytuacja taka może zaistnieć w kilku różniących się zasadniczo stanach faktycznych i prawnych. Może ona być następstwem: 1. naruszenia przez płatnika obowiązku terminowego obliczenia, potrącenia i opłacenia składki; 2. konsekwencją ustalenia, że między stronami na przykład formalnej umowy o dzieło istniała umowa o świadczenie usług, do której zgodnie z k.c. stosuje się przepisy o zleceniu; 3 . ustalenia istnienia stosunku pracy (art. $22 \S 1$ k.p. w zW. z art. 189 k.p.c.).

Przystępując do analizy zasygnalizowanego problemu, warto przytoczyć pogląd wyrażony w doktrynie prawa podatkowego, że, po pierwsze, ,autonomia prawa podatkowego oznacza przede wszystkim autonomiczność ustawodawcy podatkowego", po drugie:

brak określonej regulacji w prawie podatkowym nie oznacza zatem luki w prawie [...], lecz stanowi świadome odesłanie przez prawodawcę do przepisów prawa cywilnego [...], zgodnie z zasadą, iż prawo podatkowe jest częścią obowiązującego w Polsce porządku prawnego. Wszędzie tam, gdzie prawodawca nie korzysta $\mathrm{z}$ autonomii prawa podatkowego [...], należy $\mathrm{w}$ imię zasad zupełności i spójności systemu prawa — posługiwać się wykładnią systemową zewnętrzną prawa podatkowego, pozwalającą na odpowiednie stosowanie w tym prawie instytucji prawa cywilnego ${ }^{3}$.

Zgodnie z tym w razie stwierdzenia, że dane zachowanie w określonej gałęzi prawa (na przykład w prawie podatkowym czy prawie ubezpieczeń społecznych) jest prawnie indyferentne i jednocześnie brakuje podstaw do uznania luki extra legem ${ }^{4}$ wypełnianej w drodze analogia legis, zachowanie zaś to jest uregulowane w prawie cywilnym, należałoby określić skutki prawne tego zachowania odpowiednim zastosowaniem przepisów prawa cywilnego.

Pojawia się zatem pytanie, czy w podobny sposób należy postrzegać relację prawa ubezpieczeń społecznych do prawa cywilnego. Czy w taki sposób należy rozumieć i stosować postulat zupełności systemu prawa. Czy pozwala on na uznanie, że brak określonej regulacji prawnej w prawie ubezpieczeń społecznych przy jednoczesnym jej występowaniu w prawie cywilnym (na przykład bezpodstawne wzbogacenie, spełnienie świadczenia przez osobę trzecią) oznacza odesłanie do

2 III PZP 6/13.

${ }^{3}$ R. Mastalski, Autonomia prawa podatkowego a spójność i zupetność systemu prawa, „Przegląd Podatkowy" 2003, nr 10, s. 15-16.

${ }^{4}$ Na temat luki w prawie zob. W. Lang, J. Wróblewski, S. Zawadzki, Teoria państwa i prawa, Warszawa 1979, s. 367. 
regulacji prawnej ubezpieczeń społecznych, otwierające drogę do zastosowania przepisów kodeksu cywilnego.

$Z$ tej perspektywy warto spojrzeć na rolę przepisu art. 300 k.p. Jest on wielokrotnie powoływany w doktrynie i judykaturze jako przykład określenia relacji prawa pracy do prawa cywilnego i jednocześnie jako dowód na to, że analogicznej regulacji nie mamy w odniesieniu do prawa cywilnego i prawa ubezpieczeń społecznych. Przyjmując przedstawione tu znaczenie kierowanego do podmiotów stosujących prawo postulatu zupełności systemu prawa, należałoby uznać, że przepis art. 300 k.p. w istocie ogranicza możliwość zastosowania do stosunku pracy przepisów prawa cywilnego, ponieważ takiego ograniczenia nie mamy na gruncie relacji prawo cywilne a prawo ubezpieczeń społecznych. Ograniczenie to polega na wskazaniu, że, po pierwsze, do stosunku pracy można zastosować tylko przepisy prawa cywilnego zawarte w kodeksie cywilnym, po drugie, jest to możliwe jedynie w razie stwierdzenia luki extra legem, po trzecie, dopuszcza się jedynie odpowiednie zastosowanie przepisów cywilnoprawnych i wreszcie, po czwarte, proces ten nie może być sprzeczny z zasadami prawa pracy. Konsekwentnie zatem należałoby przyjmować — wobec braku odpowiednika przepisu art. 300 k.p. w prawie ubezpieczeń społecznych — że przepisy prawa cywilnego znajdują zastosowanie do stosunków ubezpieczenia społecznego w znacznie szerszym zakresie niż na przykład w prawie pracy.

\section{BRAK REGULACJI W PRAWIE UBEZPIECZEŃ SPOŁECZNYCH — ŚWIADOME ODESŁANIE DO KODEKSU CYWILNEGO CZY OBSZAR POZA REGULACJĄ PRAWNĄ?}

Zasygnalizowane zagadnienie warto przeanalizować na tle praktycznego problemu związanego z tym, że ustawodawca nie reguluje wprost w prawie ubezpieczeń społecznych skutków prawnych sytuacji opłacenia przez płatnika z własnych środków części składki, finansowanej przez ubezpieczonego, to jest bez potrącenia jej z przychodu ubezpieczonego.

Pojawia się zatem pytanie, czy można $\mathrm{w}$ tym zakresie — zgodnie z postulatem zupełności systemu prawa - zastosować przepisy k.c. o bezpodstawnym wzbogaceniu (art. 405-410 k.c.) albo przepisy dotyczące spełnienia świadczenia przez osobę trzecią (art. 474 k.c.). Jak należy w tym kontekście ten postulat postrzegać?

Zupełność systemu prawa jako postulat obowiązujący podmioty stosujące prawo można rozumieć także $\mathrm{w}$ inny sposób niż przedstawiony w cytowanym opracowaniu ${ }^{5}$. Istota postulatu zupełności systemu prawa przejawia się na przykład w stosowaniu ściśle określonych specyficznych przepisów prawa cywilnego

\footnotetext{
5 R. Mastalski, op. cit.
} 
do stosunków prawnych powstałych na gruncie innych gałęzi prawa. Otóż można w przepisach prawa cywilnego wyróżnić takie, które zawierają normy o zasięgu wykraczającym poza zakres prawa cywilnego, na przykład określające zdolność prawną na użytek całego systemu prawa czy pojęcia: rozwód, małżeństwo, przysposobienie. Podobny charakter mają przepisy kodeksu cywilnego, które wyrażają „myśli ogólne, obowiązujące w całej zasadniczo kulturze prawnej”6 (art. 3 k.c. - niedziałanie ustawy wstecz czy art. 6 k.c. — rozkład ciężaru dowodu). Uniwersalny charakter ma także norma zawarta w przepisie art. 358 k.c., dotycząca wyrażania zasadniczo zobowiązań pieniężnych w walucie polskiej. Mające ów walor uniwersalny przepisy zawarte $\mathrm{w}$ prawie cywilnym stosuje się $\mathrm{w}$ prawie ubezpieczeń społecznych w myśl postulatu zupełności systemu prawa, właśnie bez konieczności ustalania luki i sięgania po analogię. Nie dotyczy to jednak przepisów niemających wspomnianego waloru uniwersalnego, do których należy na przykład instytucja świadczeń nienależnych i bezpodstawnego wzbogacenia (art. 405-410 k.c.) czy też przepisy dotyczące spełniania świadczenia przez osobę trzecią (art. 474 k.c.).

Za takim rozumieniem postulatu zupełności systemu prawa przemawia także to, że nie regulując pewnych kwestii w prawie ubezpieczeń społecznych, ustawodawca zamieszcza w poszczególnych przepisach tego prawa bezpośrednie odesłania na przykład do kodeksu postępowania administracyjnego, kodeksu cywilnego czy ustawy Ordynacja podatkowa. Kierując się założeniem racjonalności ustawodawcy, uznać zatem możemy, że samo pozostawienie przez prawodawcę pewnych zachowań poza sferą regulacji prawnej ubezpieczeń społecznych, przy jednoczesnym braku wyraźnego odesłania do prawa cywilnego, nie tworzy podstawy do nadania im prawnego znaczenia przez zastosowanie odpowiednich przepisów prawa cywilnego (przez stwierdzenie luki extra legem).

\section{STWIERDZENIE LUKI W PRAWIE UBEZPIECZEŃ SPOŁECZNYCH W KONTEKŚCIE RELACJI PŁATNIK SKŁADEK-UBEZPIECZONY A ZAŁOŻENIE RACJONALNOŚCI JĘZYKOWEJ PRAWODAWCY}

Zakładając, że prawo ubezpieczeń społecznych może być regulacją niezupełną ${ }^{7}$, pozostaje rozważenie $\mathrm{w}$ interesującym mnie zakresie możliwości zastosowania przepisów o świadczeniu nienależnym i bezpodstawnym wzbogaceniu,

6 T. Zieliński, Stosowanie przepisów i pojęć prawa cywilnego w sprawach z zakresu ubezpieczeń społecznych, „Studia Cywilistyczne” 35, 1989, s. 39.

${ }^{7}$ Należy jednak podkreślić, że K. Antonów twierdzi, odwołując się do przekonania o ścisłości prawa ubezpieczeń społecznych, że prawo to stanowi zupełny system norm, idem, Stosunek prawa ubezpieczeń społecznych do prawa cywilnego, [w:] Każdy ma prawo do... Ochrona praw człowieka w świetle przepisów prawa pracy i zabezpieczenia społecznego, red. A.M. Świątkowski, Warszawa 2009, s. 316-317. 
ewentualnie o spełnieniu świadczenia przez osobę trzecią per analogiam, z powodu stwierdzenia luki technicznej ${ }^{8} \mathrm{~W}$ przepisach prawa ubezpieczeń społecznych dotyczących dochodzenia należności z tytułu składek oraz określających relację płatnik-ubezpieczony.

Powstaje pytanie, czy można uznać, że prawo ubezpieczeń społecznych jest niezupełne, że występuje w nim luka techniczna, to jest prawo to wyznacza pozytywne konsekwencje określonego faktu (zapłacenia przez płatnika z własnych środków części składki finansowanej przez ubezpieczonego; inaczej rzecz ujmując — zobowiązuje ubezpieczonego nie tylko do finansowania składki, lecz także do jej opłacenia), ale czyni to w sposób niepełny, bez elementu pozwalającego na wydanie pozytywnego rozstrzygnięcia wobec ubezpieczonego (roszczenie regresowe lub decyzja zobowiązująca bezpośrednio ubezpieczonego do opłacenia składki).

Po pierwsze, w prawie ubezpieczeń społecznych mamy uregulowaną instytucję nienależnie pobranych świadczeń, czyli „odmienne” stanowisko ustawodawcy w kwestii traktowania „nienależnych” korzyści uzyskanych na podstawie przepisów prawa ubezpieczeń społecznych, wyrażone expressis verbis.

Po drugie, zawarta w ustawie z dnia 13 października 1998 roku o systemie ubezpieczeń społecznych ${ }^{9}$ oraz we wskazanych w art. 31 ustawy systemowej przepisach ustawy z dnia 29 sierpnia 1997 roku — Ordynacja podatkowa ${ }^{10}$ regulacja obowiązków płatnika, egzekucji należności z tytułu składek itp. tworzy regulację pełną, pozbawioną luk technicznych. W każdym razie brakuje przepisu, wedle którego można by uznać, że na ubezpieczonym spoczywają obowiązki związane z realizacją należności z tytułu składek, że jego zachowanie w tym wypadku (niesfinansowanie ze swoich środków części składki lub niepotrącenie przez płatnika należnych składek z przychodu ubezpieczonego) jest jakoś pozytywnie przez prawo uregulowane, niemniej brakuje środków prawnych pozwalających na wyegzekwowanie skutków prawnych tej powinności (luka techniczna).

Otóż z regulacji tej jednoznacznie wynika, że choć część składki na ubezpieczenie emerytalne, rentowe oraz całą składkę na ubezpieczenie chorobowe finansuje ubezpieczony $\mathrm{z}$ własnych środków ${ }^{11}$, to jednak podmiotem mającym status dłużnika w odniesieniu do całej składki, zarówno w części finansowanej przez ubezpieczonego, jak i płatnika, jest jednak płatnik składek ${ }^{12}$. Zgodnie bowiem z przepisem art. 24 ust. 2 i następnych ustawy systemowej płatnik składek jest nazwany expressis verbis dłużnikiem z tytułu należności składkowych. Termin

${ }^{8}$ Luka ta polega na tym, że reguły wyznaczające konsekwencje faktu nie są kompletne w tym sensie, że nie regulują jakiegoś elementu instytucji, bez którego orzeczenie konsekwencji pozytywnych nie jest możliwe, zob. W. Lang, J. Wróblewski, S. Zawadzki, op. cit., s. 367-368.

9 Tekst jedn. Dz.U. z 2019 r. poz. 300; dalej: ustawa systemowa.

10 Tekst jedn. Dz.U. z 2019 r. poz. 900; dalej: Ordynacja podatkowa.

11 J. Wantoch-Rekowski, Sktadka w ubezpieczeniu emerytalnym. Konstrukcja i charakter prawny, Toruń 2005, s. 103; por. inaczej K. Antonów, Prawo do emerytury, Warszawa 2003, s. 84.

12 Zob. inaczej W. Sanetra, op. cit., s. 2. 
zaś „należności z tytułu składek” obejmuje, w myśl art. 24 ust. 2 ustawy systemowej, składki, odsetki za zwłokę, koszty egzekucyjne, koszty upomnienia i dodatkową opłatę. Należą do nich także te części składek na poszczególne rodzaje ubezpieczeń społecznych, które finansowane są w myśl ustawy systemowej przez ubezpieczonego (z własnych środków) niebędącego jednocześnie płatnikiem składek $^{13}$. Ponadto także przepisy Ordynacji podatkowej, do których odsyła przepis art. 31 ustawy systemowej, jako mające zastosowanie do należności z tytułu składek, jednocześnie adresowane są wyłącznie do płatnika. To na płatniku, a nie ubezpieczonym niebędącym płatnikiem, spoczywa ciężar poniesienia „należności z tytułu składek" (art. 24 ust. 2 i inne ustawy systemowej). Skoro przepisy Ordynacji podatkowej, do których odsyła przepis art. 31 ustawy systemowej, stosuje się do „należności z tytułu składek”, to uznać należy, że są one adresowane wyłącznie do płatnika składek.

Zasadna więc jest konkluzja, że w rozumieniu przepisów Ordynacji podatkowej ,podatnik” to „płatnik składek” na gruncie ubezpieczeń społecznych. Oznacza to, że - w myśl mającego odpowiednie zastosowanie przepisu art. 26 Ordynacji podatkowej — za należności z tytułu składek całym swoim majątkiem odpowiada wyłącznie płatnik składek. Zachowując racjonalność językową, prawodawca nie nakazuje jednocześnie stosowania odpowiednio do określenia obowiązków płatnika składek tych przepisów Ordynacji podatkowej, które wprost odnoszą się do płatnika lub inkasenta (art. $30 \mathrm{i}$ inne Ordynacji podatkowej). W zakresie dotyczącym obowiązków płatnika składek związanych z czynnościami technicznym (obliczania, rozliczania, potrącania i przekazywania składek) mamy pełną regulację zawartą w ustawie systemowej.

Dlatego też — zachowując racjonalność językową — prawodawca nie zawarł w ustawie systemowej odesłania do przepisu art. 26a $\S 1$ Ordynacji podatkowej. Przepis ten stanowi, że podatnik nie ponosi odpowiedzialności z tytułu zaniżenia lub nieujawnienia przez płatnika podstawy opodatkowania czynności, o których mowa w art. 12, art. 13 oraz art. 18 ustawy z dnia 26 lipca 1991 roku o podatku dochodowym od osób fizycznych, do wysokości zaliczki, do której pobrania zobowiązany jest płatnik. Jak już wskazano, przepisy Ordynacji podatkowej adresowane do „podatnika” dotyczą — na gruncie stosunków prawnych ubezpieczenia społecznego - płatnika składek, a nie ubezpieczonego. Inaczej rzecz ujmując, mające odpowiednie zastosowanie do stosunku ubezpieczenia społecznego przepisy Ordynacji podatkowej adresowane są wyłącznie do płatnika składek ${ }^{14}$. Interpretacja, wedle której płatnik składek jest na gruncie mających odpowiednie zastosowanie przepisów Ordynacji podatkowej podatnikiem, uzasadnia także brak odesłania w ustawie systemowej do na przykład przepisu art. 30 Ordynacji podat-

13 D. Dzienisiuk, Prawo pracy a prawo ubezpieczeń społecznych, Warszawa 2016, s. 359.

14 Art. 26a § 1 Ordynacji podatkowej: ,,podatnik nie ponosi odpowiedzialności z tytułu zaniżenia lub nieujawnienia przez płatnika podstawy opodatkowania czynności, o których mowa [...], do wysokości zaliczki, do której pobrania zobowiązany jest płatnik". 
kowej. W myśl tego przepisu za podatek niepobrany lub podatek pobrany, a niewpłacony odpowiada płatnik, a nie podatnik, chyba że odrębne przepisy stanowią inaczej albo jeżeli podatek nie został pobrany $z$ winy podatnika. Przepis ten ma sens jedynie wtedy, gdy przyjmujemy, że występuje odrębność podmiotowa między podatnikiem a płatnikiem. Tymczasem, z powodu odpowiedniego stosowania przepisów Ordynacji podatkowej do „należności z tytułu składek”, należy przyjąć konsekwentnie - kierując się założeniem racjonalności językowej prawodawcy — tożsamość pojęciową „podatnika” (Ordynacja podatkowa) i płatnika składek (ustawa systemowa).

Płatnik składek i płatnik podatku to dwie różne kategorie prawne, podobnie jak podatek i składka na ubezpieczenia społeczne ${ }^{15}$. To uzasadnia odmienne reguły ukształtowania pozycji płatnika składek względem ubezpieczonego oraz płatnika zaliczki na podatek czy inkasenta względem podatnika, nawet jeśli są to $\mathrm{w}$ danym stanie faktycznym te same osoby. Dlatego też nie ma powodów do poszukiwania drogi zastosowania w szerszym stopniu i zakresie przepisów Ordynacji podatkowej, w tym przepisu art. 30, do stosunków prawnych ubezpieczenia społecznego (relacji płatnik składek-ubezpieczony). Między „płatnikiem” w stosunku ubezpieczenia społecznego a „płatnikiem” w świetle zobowiązań podatkowych występuje jedynie podobieństwo formalnojęzykowe, a nie pojęciowe. Do płatnika składek stosuje się przepisy Ordynacji podatkowej adresowane do podatnika, a nie płatnika czy inkasenta ${ }^{16}$.

\section{ZASTOSOWANIE PRZEPISÓW KODEKSU CYWILNEGO} DO RELACJI PŁATNIK SKŁADEK-UBEZPIECZONY

\section{A RACJONALNOŚĆ JĘZYKOWA I AKSJOLOGICZNA PRAWODAWCY}

W kontekście prowadzonych rozważań pojawia się także pytanie o adekwatność regulacji dotyczącej bezpodstawnego wzbogacenia i świadczenia nienależnego (art. 405 i 410-411 k.c.) do sytuacji, w której płatnik opłacił i sfinansował z własnych środków część składki finansowanej przez ubezpieczonego niebędącego płatnikiem. Zgodnie z poglądami doktryny oraz judykatury pracodawca po zapłaceniu składki także w części finansowanej przez ubezpieczonego z własnych środków może dochodzić zwrotu zapłaconej kwoty na podstawie przepisów o bezpodstawnym wzbogaceniu (art. 405 k.c. i następne w zw. z art. 300 k.p. $)^{17}$.

Nawet jeśli uznamy, że pracownik lub zleceniobiorca uzyskał korzyść kosztem pracodawcy lub zleceniodawcy, bo nie potrącono z jego wynagrodzenia należnych

15 Por. J. Wantoch-Rekowski, op. cit., s. 112.

16 Zob. podobnie ibidem, s. 135.

17 Zob. D. Dzienisiuk, op. cit., s. 361 i powołana tam literatura; uchwała SN z 5 grudnia 2013 roku, III PZP 6/13. 
składek, to pojawi się pytanie, czy możemy uznać go za bezpodstawnie wzbogaconego w rozumieniu art. 405 i 410 k.c. Pracodawca (ewentualnie zleceniodawca lub zamawiający dzieło) wypłaca wynagrodzenie w kwocie umówionej za wykonaną pracę (dzieło). Wypłata wynagrodzenia bez potrącenia należnych składek nie następuje zatem bez podstawy prawnej. Sprawa ta jest szczególnie oczywista, gdy strony wiąże — zgodnie z ich wolą — umowa o dzieło, która następnie (po wielu miesiącach a nawet latach) zostanie - na gruncie prawa ubezpieczeń społecznych - zakwalifikowana przez organ rentowy lub sąd jako na przykład umowa o świadczenie usług stanowiąca tytuł obowiązkowego ubezpieczenia społecznego zgodnie z przepisem art. 6 ust. 1 pkt 4 ustawy systemowej. Istotne jest jednak to, że w chwili wykonania umowy (umowy o dzieło) i zapłaty wynagrodzenia nie możemy mówić o świadczeniu nienależnym z powodu braku zobowiązania do świadczenia czy nieważności czynności prawnej (umowy). W przypadku uznania, że strony łączy na przykład umowa o świadczenie usług (art. 6 ust. 1 pkt 4 ustawy systemowej), a nie umowa o dzieło, nie jest bowiem koniecznie stwierdzenie nieważności umowy o dzieło. Uznanie, że mamy tytuł obowiązkowego ubezpieczenia społecznego, następuje na podstawie art. 6 ust. 1 pkt 4 ustawy systemowej bez konieczności kwestionowania na gruncie prawa cywilnego (art. 58 k.c.) ważności samej umowy o dzieło. Do celów obrotu cywilnoprawnego (poza reżimem prawa ubezpieczeń społecznych) oraz innych strony mogą dalej uznawać, że łączy je umowa o dzieło. Prawo ubezpieczeń społecznych z jednej strony i prawo cywilne $z$ drugiej są autonomicznymi gałęziami prawa. Do ustalenia tytułu obowiązkowego ubezpieczenia emerytalnego i rentowego wystarczy stwierdzenie, że praca była wykonywana na podstawie umowy, która odpowiada istocie umowy zlecenia czy innej umowy o świadczenie usług (art. 6 ust. 1 pkt 4 ustawy systemowej). Tym samym brakuje podstaw do uznania na gruncie prawa cywilnego, że wykonawca dzieła, otrzymując wynagrodzenie bez potrącenia należnych składek, otrzymał świadczenie bez podstawy prawnej.

W odniesieniu do relacji pracownik-pracodawca w uchwale SN z 5 grudnia 2013 roku dopuszczono także — jak się zdaje bezrefleksyjnie ${ }^{18}$ — dochodzenie, na podstawie przepisów o bezpodstawnym wzbogaceniu (art. 405 k.c. i następne w zW. z art. 300 k.p.), przez pracodawcę od pracowników zwrotu opłaconych z własnych środków przez pracodawcę (płatnika) części składek finansowanych w myśl ustawy systemowej przez ubezpieczonych. Pominięto tutaj kwestię odrębności prawa pracy i prawa ubezpieczeń społecznych oraz określonych tymi gałęziami prawa powinności i uprawnień odpowiednio stron stosunku pracy oraz stron relacji kształtowanej prawem ubezpieczeń społecznych ubezpieczony-płatnik. W tej sytuacji wypłata pracownikowi wynagrodzenia w określonej wysoko-

18 Refleksja dotyczyła kwestii rozumienia „bezpodstawnego wzbogacenia” i „zubożenia” oraz tego, od jakiego momentu zaczyna biec termin przedawnienia roszczenia pracodawcy o zwrot zapłaconej składki w części finansowanej przez pracownika, bez wcześniejszego jej potrącenia z wynagrodzenia tego pracownika. 
ści przez pracodawcę nie może zostać potraktowana jako bezpodstawna korzyść pracownika. Podstawę do tej wypłaty stanowią akt nawiązania stosunku pracy, wykonanie umówionej pracy, postanowienia autonomicznych źródeł prawa pracy oraz określone przepisy kodeksu pracy lub innych ustaw (art. 21 k.p. i inne źródła prawa do wynagrodzenia za pracę). Jeśli zatem pozostawiając do dyspozycji pracownika wynagrodzenie w określonej wysokości, nie naruszono postanowień umowy o pracę oraz przepisów prawa pracy, to nie sposób przyjąć, że zostało ono wypłacone nienależnie.

Obliczenie, rozliczenie, potrącenie oraz odprowadzenie składek są obowiązkami płatnika składek, a nie pracodawcy, podlegającymi regulacji prawa ubezpieczeń społecznych. Dokonując potrącenia składek z przychodu ubezpieczonego, finansowanych przez tego ubezpieczonego czy też - opłacając je po terminie — z własnych środków, pracodawca staje się płatnikiem składek realizującym powinności określone w prawie ubezpieczeń społecznych. $Z$ tego punktu widzenia jednak opłacenie składek za ubezpieczonego nie może być uznane jako bezpodstawne wzbogacenie pracownika kosztem pracodawcy.

Ponadto, respektując niezależność prawa ubezpieczeń społecznych względem prawa pracy, uznać należy, że relacja między tymi dziedzinami prawa sprowadza się między innymi do określenia przez prawo ubezpieczeń społecznych specyficznych następstw nawiązania stosunku pracy w postaci powstania ex lege odrębnego stosunku ubezpieczenia społecznego. W konsekwencji, oceniając na gruncie prawa ubezpieczeń społecznych skutki dokonanej na podstawie prawa pracy czynności prawnej, należy — zakładając racjonalność prawodawcy — stosować przepisy i terminologię adekwatną do prawa ubezpieczeń społecznych. W doktrynie zauważa się zatem, że składka jest świadczeniem pieniężnym, przymusowym, celowym, odpłatnym i bezzwrotnym ${ }^{19}$. Można by zatem dowodzić, że płatnik, opłacając z własnych środków (finansując) część składki finansowanej w myśl ustawy systemowej przez ubezpieczonego, spełnił świadczenie jako osoba trzecia. Pytanie, czy przepis art. 474 k.c. jest jednak adekwatny do specyfiki tej sytuacji, która zaistniała i została wykreowana przepisami prawa ubezpieczeń społecznych. Stosunek ubezpieczenia społecznego, w tym relacja zachodząca między płatnikiem a ubezpieczonym, jest samoistnym, odrębnym stosunkiem prawnym od stosunku cywilnoprawnego. Stosunki zobowiązaniowe nie tworzą bowiem autonomicznej domeny prawa cywilnego, lecz występują jako na przykład zobowiązaniowe stosunki ubezpieczeniowe. Stosunek zachodzący między ubezpieczonym a płatnikiem składek charakteryzuje się jednostronnością ustawowych obowiązków nałożonych na płatnika. Regulacja ta jest pełna w tym sensie, że nie można uznać, iż przepisy prawa ubezpieczeń społecznych regulują jakieś zachowanie ubezpieczonego w relacji do płatnika w sposób niepełny, prowadząc do powstania

19 J. Wantoch-Rekowski, op. cit., s. 99. 
luki technicznej. Nie pozwala na to - o czym była mowa — założenie racjonalności językowej ustawodawcy.

Poza tym przepis art. 474 k.c. odnosi się do spełnienia świadczenia za dłużnika. W świetle tych ustaleń, dotyczących ukształtowania w ustawie systemowej sytuacji ubezpieczonego i płatnika $\mathrm{w}$ razie opłacenia przez płatnika $\mathrm{z}$ własnych środków po terminie składki finansowanej przez ubezpieczonego, dłużnikiem jest płatnik, a nie ubezpieczony. Oznacza to, że brakuje podstaw do uznania, że sytuacja ta odpowiada konstrukcji spełnienia świadczenia przez osobę trzecią. W tym wypadku to płatnik realizuje, ciążące wyłącznie na nim, należności z tytułu składek i odpowiada za to całym swoim majątkiem. Inaczej wygląda kwestia realizacji uprawnień, w które zostali wyposażeni względem płatnika sami ubezpieczeni. W doktrynie dostrzega się, że ustawy z zakresu ubezpieczeń społecznych nakładają na płatników obowiązki, dając uprawnienia ubezpieczonym, nie określają zaś możliwości skutecznego żądania ich wykonania. Dlatego też wskazuje się, że ochronę tę ubezpieczeni mogą realizować na gruncie prawa cywilnego ${ }^{20}$.

Wobec tego należy uznać, że brakuje racji i podstaw prawnych do zastosowania przepisów kodeksu cywilnego w celu zobowiązania ubezpieczonego do zwrotu płatnikowi części składki finansowanej w myśl ustawy przez ubezpieczonego, a opłaconej przez tego płatnika z własnych środków, to jest bez potrącenia jej z przychodu ubezpieczonego. Uwaga ta dotyczy zarówno określenia tego typu powinności na gruncie prawa ubezpieczeń społecznych (nie ma luki technicznej oraz nieadekwatności przepisu art. 474 k.c.), jak i prawa pracy (pracownik-pracodawca) czy prawa cywilnego (zleceniobiorca i zleceniodawca) ze względu na nieistnienie podstaw prawnych do uznania, że uzyskane wynagrodzenie w wysokości bez potrącenia należnych składek jest bezpodstawnym wzbogaceniem pracownika lub zleceniobiorcy.

Pozostaje jeszcze argument natury ogólnej, odwołujący się do zasad i funkcji ubezpieczeń społecznych oraz uwzględniający założenie racjonalności aksjologicznej prawodawcy ${ }^{21}$. Stosując prawo ubezpieczeń społecznych, należy eliminować czynniki, które by stały na przeszkodzie w motywowaniu osoby wykonującej pracę zarobkową do podejmowania działań zmierzających do zapewnienia sobie ochrony socjalnej. Uznanie, że w razie skutecznego wytoczenia powództwa o ustalenie istnienia stosunku pracy pracownik-ubezpieczony byłby obciążony obowiązkiem zwrotu na rzecz pracodawcy-płatnika składek kwoty zapłaconych składek za okresy wsteczne, w części obejmującej składki finansowane w myśl ustawy przez ubezpieczonego, stałoby w sprzeczności z funkcją motywacyjną i ochronną prawa ubezpieczeń społecznych (prawa zabezpieczenia społecznego). Takiego rozwiązania nie można także zaakceptować z punktu widzenia założenia racjonalności ustawodawcy. Racjonalny ustawodawca bowiem to podmiot, który kieruje się w swoim postępowaniu w sposób konsekwentny posiadaną wiedzą

20 K. Antonów, Stosunek prawa ubezpieczeń..., s. 309-310.

21 Z. Ziembiński, Wstęp do aksjologii prawa dla prawnika, Warszawa 1990, s. 165. 
i przyjmowanymi przez siebie ocenami (systemem wartości), dlatego na gruncie posiadanej wiedzy i żywionych ocen wybiera takie spośród możliwych w danej sytuacji działanie, które prowadzi do optymalnych stanów rzeczy ${ }^{22}$. Reasumując, interpretacja przepisów ustawy systemowej oraz odpowiednich przepisów Ordynacji podatkowej, do których ustawa systemowa odsyła, uwzględniająca założenie zwłaszcza językowej racjonalności prawodawcy pozostaje w zgodzie z ustaleniami odwołującymi się do założenia aksjologicznej i prakseologicznej racjonalności prawodawcy $^{23}$.

\title{
THE ISSUE OF APPLYING THE PROVISIONS OF THE CIVIL CODE TO DETERMINE SOME CONSEQUENCES OF THE RELATIONSHIP BETWEEN THE PAYER AND THE INSURED FROM THE POINT OF VIEW OF ASSUMING THE RATIONALITY OF THE LEGISLATOR
}

\author{
Summary
}

The article analyses the problem of admissibility and legal grounds for the payer to claim from the insured the return of a part of the premium paid from the payer's own resources, which according to the Act is financed by the insured. The study attempts to assess whether there is a gap in social insurance law in this case, or whether it can be based on another basis - by applying the provisions of the Civil Code on unjust enrichment or third party performance - to formulate an appropriate recourse claim of the contribution payer against the insured. Assumptions about the legislator's linguistic and axiological rationality were made as a reference point for the considerations and interpretations of legal provisions.

Keywords: contribution payer, insured, civil law, social insurance law, assumption of the legislator's rationality

\section{BIBLIOGRAFIA}

Antonów K., Prawo do emerytury, Warszawa 2003.

Antonów K., Stosunek prawa ubezpieczeń społecznych do prawa cywilnego, [w:] Każdy ma prawo do... Ochrona praw człowieka w świetle przepisów prawa pracy i zabezpieczenia społecznego, red. A.M. Świątkowski, Warszawa 2009.

Dzienisiuk D., Prawo pracy a prawo ubezpieczeń społecznych, Warszawa 2016.

Lang W., Wróblewski J., Zawadzki S., Teoria państwa i prawa, Warszawa 1979.

Mastalski R., Autonomia prawa podatkowego a spójność i zupetność systemu prawa, „Przegląd Podatkowy" 2003, nr 10.

Sanetra W., Pracownik i płatnik składki, PUSiG 2000, nr 1.

22 Ibidem, s. 162.

23 Zob. więcej na ten temat ibidem, s. 167; M. Zieliński, Wyktadnia prawa. Zasady, reguły, wskazówki, Warszawa 2008, s. 309. 
Wantoch-Rekowski J., Skladka w ubezpieczeniu emerytalnym. Konstrukcja i charakter prawny, Toruń 2005 .

Zieliński M., Wykładnia prawa. Zasady, reguły, wskazówki, Warszawa 2008.

Zieliński T., Stosowanie przepisów i pojęć prawa cywilnego $w$ sprawach z zakresu ubezpieczeń społecznych, „Studia Cywilistyczne” 35, 1989.

Ziembiński Z., Wstęp do aksjologii prawa dla prawnika, Warszawa 1990. 